\title{
On How to Improve College Sports Badminton Teaching Level
}

\author{
Fanwei Meng \\ Changchun University of science and technology, Changchun 130000, China \\ 13742883@qq.com
}

\begin{abstract}
Badminton teaching as an important curriculum of college physical education teaching, to cultivate students' sports spirit and skills play a key role. In order to adapt to the modern physical education teaching mode, colleges and universities must adjust the badminton class teaching strategies, from aspects of the research of college students' physical fitness and skills, use of modern teaching methods to improve the effect of physical education teaching, stimulate the brave spirit of college students. This article through the analysis of college sports badminton teaching present situation, and then probes the strategies to improve the level of college badminton teaching, hope to offer help for sports teaching.
\end{abstract}

Keywords: College sports, Badminton, Teaching level.

\section{Introduction}

Badminton as sports ball games is popular with college students, with its flexibility, explosive and coordination and so on the characteristic of physical development and psychological development of college students has crucial significance, and plays an important role in the university campus. Regular badminton training, students can promote body all aspects of the coordination and development of mental health, cultivate optimistic, positive and fighting spirit, inspires students to form a good habit of physical exercise. At the same time, the physical education teachers have to implement the curriculum reform, the innovation teaching idea, optimize the relationship between teachers and students, build the sports classroom atmosphere active, and not only to cultivate college students' sports skills, but also exercise their sports consciousness. However, some problems still exist in college badminton teaching, seriously affected the teaching effect. Now in front of college PE teachers' important problem is how to cultivate students' initiative and creativity, improve the students' participation, and promote the students to master the skill movements of badminton faster? Here will be on your badminton teaching experience, the author talk about college badminton teaching status quo and improve the level of badminton teaching strategy.

\section{College sports badminton teaching present situation}

(1) physical education teachers teaching idea behind, with the time education disjointed seriously in contemporary university campus still exist some backward concepts, close-minded PE teachers. They don't have positive enterprising consciousness, conformism, sports teaching content with the status quo, regardless of the college students' individual differences and the actual level, teaching carried out in accordance with the unified teaching plan.Students have problems when they study in the sports action didn't answer in time, greatly hinder the development of students. A lot of university physical education teachers to the badminton teaching do not take the oneself, think learning badminton is not important, just make sure the teaching task can be completed, as to students could learn badminton related knowledge and skills also doesn't matter. In the badminton teaching by simplifying the teaching steps, don't give students free time.Such wrong ideas lead to the potential of physical education teachers in teaching students killed, unfavorable to students the initiative, but also with the time of the separation performance.

(2) students not enough emphasis on badminton, study interest is not high.College students' curiosity is strong, they face the rich and colorful university life easily attracted to new things, lead to lose 
interest in learning, especially to the employment relationship is subject more bored. In university campus, students too much focus on English and computer level 2 pass band 4 and band 6, all kinds of license certificate whether can increase its strength, the development of the society is in accordance with the personal growth, etc. For badminton class, students tend to put less energy, and even some college students when have badminton class time off to do other things. As is known to all, college students face the employment pressure, they through various means in raising their employment ability, so they are for college sports badminton teaching does not pay attention to.Based on past experience in teaching, the student's enthusiasm is not high, in the badminton class participation is not enough, lack of innovation consciousness in classroom teaching.

(3) the badminton movement skills complex, teacher's teaching is difficult. Badminton movement is not only complicated and changeable, every action of proficiency for badminton skills produce very big effect. College badminton teaching test student body coordination ability and strain capacity, if students cannot follow the teacher learning skills well, easily in the process of sports injury.Such as playing badminton, the head of action though not difficult, but it plays a big role, will be Directly affect the line of sight and balance. Often in the practical teaching, college sports teachers will not teach badminton skills of comprehensive student, but choose a few small difficulty of movement, low risk action, for the difficult, high risk of action is just let the student to carry on the simple understanding. At the same time, the sports teachers worry about students were injured because of badminton skill difficulty is too large, so they are teaching are too conservative, make the teaching difficulty is also increase.

\section{Improve the level of college sports badminton teaching strategy}

(1) the creation of good sports classroom atmosphere, stimulate students' interest in learning.

University teaching should pay attention to stimulate students' interest in learning, and mining related to badminton sports skills, develop knowledge of badminton.According to the psychological characteristics of college students, sports teachers should actively create a good classroom atmosphere, make students feel the fun of learning badminton, thus to make the students grow in fun.In sports teaching, teachers must be good at guiding students correct sports habits, more design related to badminton racket and badminton sports activities, to attract students' interests in learning.For example, when teaching students grip strength, I assume that students catch a bird in hand, grip is too tight will squeeze the bird to death, is too loose will put the birds run, step by step and inspire students' imagination, make originally boring sports content becomes more vivid.

(2) positive change education idea, the introduction of modern teaching technology.

For college PE teachers' education concept behind the phenomenon, I very the attention in the practical teaching and the modern times, the introduction of modern teaching means, enrich the sports teaching effect.Techniques for studying badminton, the importance of self-evident, but the traditional physical education teachers are often show students do it again, and then let the students free practice, doing so can not play a role.I will give the student movement decomposition teaching, make students have complete understanding about badminton movement, and then through the auxiliary practice teaching level of ascension.

(3) pay attention to step by step, distinguished talk badminton behavioral essentials.

College badminton teaching need to be distinguished, step by step, let college students to learn physical knowledge.In order to improve the students' imagination, to have a purpose and targeted in the badminton teaching, step by step, according to their aptitude, all the students are able to make some idea badminton behavioral essentials. According to the law of students receive things, I started teaching teaching from the simple, gradually improve the difficulty of movement, providing students with free room to grow. 


\section{Conclusion}

To sum up, the badminton in university sports teaching has a broad space for development, as long as the physical education teachers to recognize the reality, from the reality, theory with practice, college students' main body effect into full play, creating open classroom atmosphere, can better promote the improvement of teaching level.As a university sports teacher, I will change the teaching idea positively, learn advanced knowledge and professional skills, badminton and other sports with the students for this, for the education of high quality and comprehensive physical and mental health Talents and efforts.

\section{References}

[1] Wang yan. Northwest normal university affiliated no. 1 middle school badminton class the teaching status quo of the study [J]. Journal of information science and technology, 2016, (33): 161-162.

[2] Li Yunwei Shi Juanjuan. Badminton self-organization under the perspective of club system [J]. Journal of chifeng institute (natural science edition), 2016, (17): 171-172. Marina.

[3] Generation in badminton teaching sports injury prevention and control of [J]. Journal of asia-pacific education, 2016, (25): $143+132$.

[4] Li Yingda. Analyze the badminton teaching under the guidance of lifetime sports thought [J]. Journal of intelligence, 2016, (24): 90.

[5] China tree seed. Jilin province ordinary university badminton option class teaching present situation and countermeasure research [D]. Yanbian University, 2016.

[6] Liu. Average college badminton teaching effectiveness study [J]. Journal of sport, 2016, (5): 89-90. Enabled.

[7] Yuan badminton experience type teaching mode of study [J]. Journal of Anhui sports science and technology, 2016. (01): 83-86.

[8] Show, Chen Deng Chaohui. College students male body the investigation and analysis of badminton class learning interest and motivation - in jiangxi normal university, for example [J]. Journal of horizon of science and technology, 2016, (6): 158-159. 